\title{
Validating tree species composition in forest resource inventory for Nipissing Forest, Ontario, Canada
}

\author{
by Fred Pinto ${ }^{1}$, Dan Rouillard ${ }^{2}$, Jean-Marie Sobze ${ }^{3}$ and Michael Ter-Mikaelian ${ }^{4}$
}

\begin{abstract}
Species composition estimated from forest resource inventory (FRI) was validated using field data collected in 136 stands in Nipissing Forest (Ontario, Canada). FRI- and field-based species composition matched in 54\% and 56\% of cases using stand count and area coverage, respectively. Possible causes of discrepancy between FRI- and field-based species composition are discussed. Low level of agreement between FRI and field data indicated a need for more extensive studies on FRI validation prior to its use for forest management planning.
\end{abstract}

Key words: forest resource inventory, FRI, forest unit, photo-interpretation, timber cruise

\section{RÉSUMÉ}

La composition en espèces estimée à partir de l'inventaire des ressources forestières (IRF) a été validée au moyen des données de terrain recueillies dans 136 peuplements de la forêt de Nipissing (Ontario, Canada). L'IRF et la composition en espèces sur le terrain ont concordé pour $54 \%$ et $56 \%$ des cas en utilisant respectivement un décompte des peuplements et le recouvrement en superficie. Les causes probables de différence entre l'IRF et la composition en espèces sur le terrain font l'objet de discussion. Le faible taux de concordance entre l'IRF et les données du terrain indiquent la nécessité d'avoir des études plus exhaustives de la validité de l'IRF avant son utilisation à des fins d'aménagement forestier.

Mots clés : inventaire des ressources forestières, IRF, unité forestière, photo-interprétation, inventaire d'exploitation

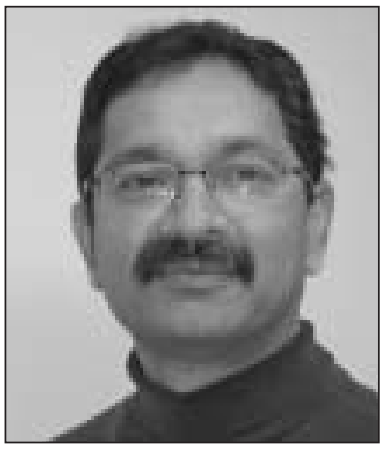

Fred Pinto

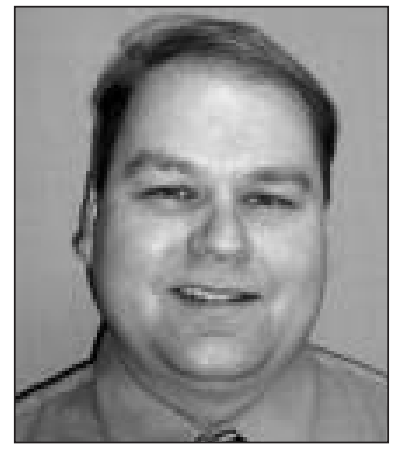

Dan Rouillard

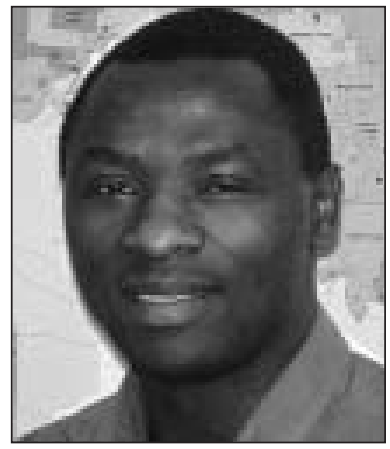

Jean-Marie Sobze

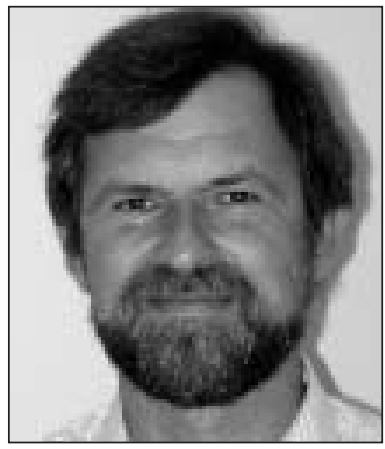

Michael Ter-Mikaelian

\section{Introduction}

The main source of information for forest management planning in Ontario is the Forest Resource Inventory (FRI). In general, a forest resource inventory may be defined as a survey of an area to provide information on the present extent, composition, structure and location of the forest (Gillis and Leckie 1993). In Ontario, the FRI is conducted on a cycle of approximately 20 years. The primary data sources for FRI production are aerial photographs taken at 1:20 000 for northern Ontario and 1:10 000 for southern Ontario. These photographs are used to delineate forest stands and assess other stand attributes through interpretation of photos calibrated with timber cruise plots established subjectively in

stands representing either typical forest condition or areas of uncertainty. If available, other sources of information (such as history of recent disturbances or ground surveys) may assist photo interpretation. The interpreted stand boundaries and attribute data are later transferred onto maps to produce a FRI for a given area. The last cycle of photography for Ontario FRI was carried out from 1986 to 1997, with the photo interpretation being completed by 2003 .

One of the key stand attributes included in a forest resource inventory is tree species composition, which details most common tree species in a stand listed in descending order of percentage of crown occupancy (Gillis and Leckie 1993). Species content is given to the nearest $10 \%$ and all

\footnotetext{
${ }^{1}$ Southern Science and Information Section, Ontario Ministry of Natural Resources, North Bay, Ontario. E-mail: fred.pinto@ontario.ca ${ }^{2}$ Forest Analysis and Modelling Unit, Ontario Ministry of Natural Resources, Sault Ste. Marie, Ontario. E-mail: dan.rouillard@ontario.ca ${ }^{3}$ Ontario Forest Research Institute, Ontario Ministry of Natural Resources, Sault Ste. Marie, Ontario. E-mail: jean-marie.sobze@ontario.ca ${ }^{4}$ Ontario Forest Research Institute, Ontario Ministry of Natural Resources, Sault Ste. Marie, Ontario. E-mail: michael.termikaelian@ ontario.ca
} 
species contributing at least $10 \%$ to the canopy of the stand are listed. For management purposes, species composition is converted into forest units, defined as an aggregation of forest stands with similar species composition, which are developed in a similar manner and are managed under the same silvicultural system (OMNR 2004). Each forest unit is defined by a region-specific rule that specifies the minimum content for the main species composing the unit; for some units, the rules also include minimum requirements for stand age, stocking, and site class. Forest units form the basis of large-scale forest management planning in Ontario and are used to estimate and predict timber and wildlife habitat supply and to predict successional changes during natural or management-induced stand development.

Despite continuous efforts to improve the quality of forest resource inventories, the literature contains surprisingly little information about methods of validating the information produced by means of photo interpretation. Most of the efforts appear to be focussed on automating interpretation and comparing various sources of remotely sensed information (e.g., Hyyppa et al. 2000, McRoberts et al. 2003). We are aware of only one sys-

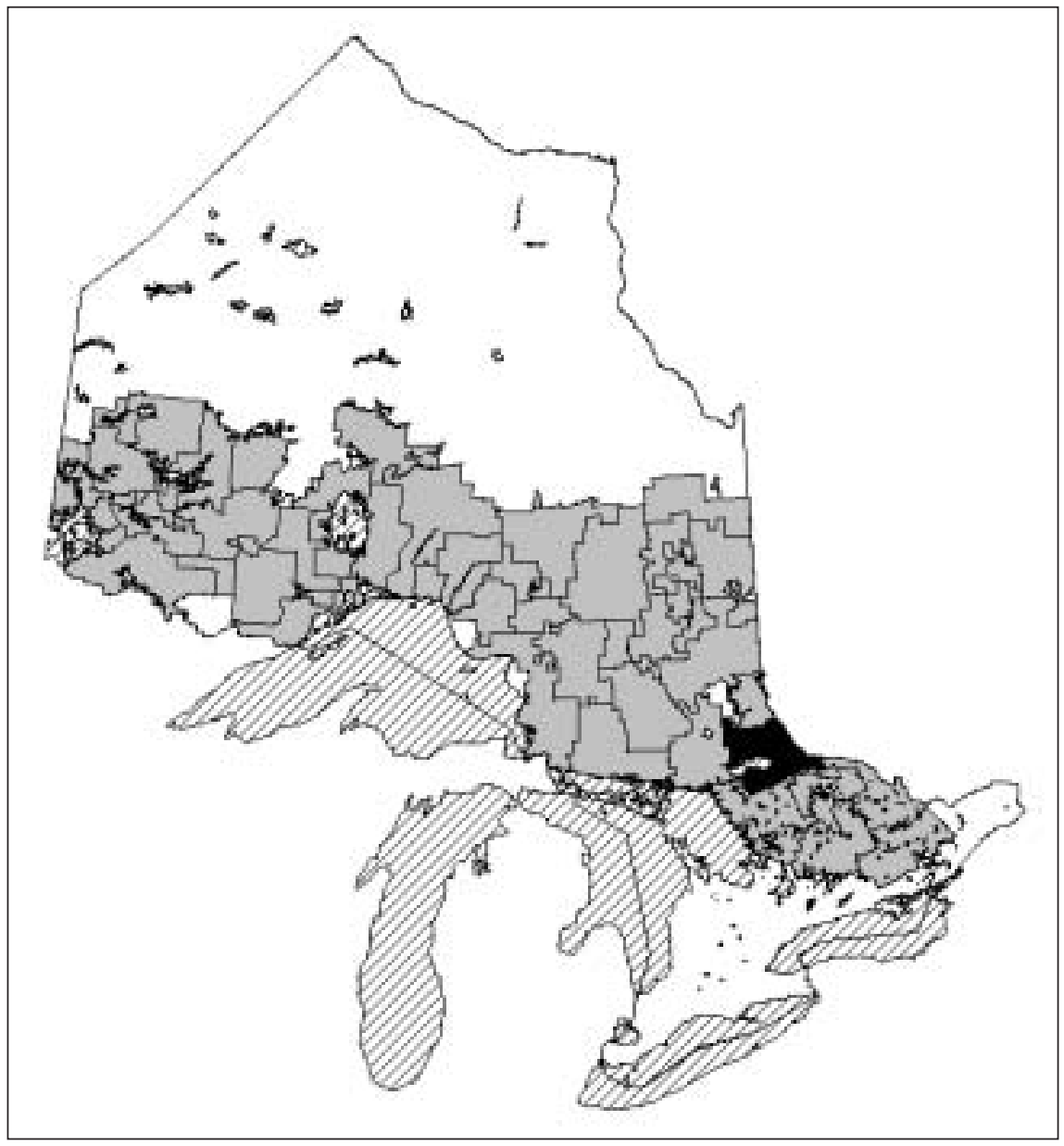

Fig. 1. Ontario's forest management units (shaded) highlighting location of Nipissing Forest (dark shaded). tematic effort to validate the information produced in a forest resource inventory: an inventory audit undertaken by the Ministry of Forests in British Columbia (BC), in 1992-1999 (BCMoF 2001). The audit reports included a comparison of species composition performed on a growth type group (similar to Ontario's forest unit) basis. The audit results showed from 30\% to $80 \%$ agreement between the growth type groups assigned in the inventory and the audit, respectively, and underscored the importance of testing forest resource inventory information with independently sampled field data.

Errors in a forest resource inventory may occur due to incorrect photo interpretation, insufficient sampling of plots used to calibrate the aerial photos, inaccurate application of formulae or look-up tables used to derive some of the stand attributes (e.g., height, site class), etc.. Propagation of these errors through planning tools such as timber supply models may result in predicted forest conditions substantially different from the actual ones.

In this paper, we report the results of a study to validate the FRI for one of Ontario's forest management units. The objectives of the study were to:

- evaluate the level of agreement between field- and FRIbased information on species composition, and

- discuss applications of the study results to forest management planning.

\section{Materials and Methods}

The study was conducted in the Nipissing Forest Management Unit (FMU) located in the Great Lakes-St. Lawrence zone of Ontario managed forest area (Fig. 1). The FMU is just over 1 million hectares including forested area, water, and other non-forest area. Approximately 593023 ha are classified as Crown productive forest available for timber production (Cottam and Street 2004). Dominant species include trembling aspen (Populus tremuloides Michx.), sugar maple (Acer saccharum Marsh.), eastern white pine (Pinus strobus L.), white birch (Betula papyrifera Marsh.), black spruce (Picea mariana (Mill.) BSP), jack pine (Pinus banksiana Lamb.), and red pine (Pinus resinosa Ait.). The most recent forest inventory for this FMU was based upon 1989 photography. Descriptive statistics for the FMU, including proportion of area in planning forest units (assigned to stands based on the species composition in the FRI) is provided in Table 1. The planning forest unit classification in this study is based on standard forest units for Northeastern Ontario. The planning forest units are at a slightly more aggregated level due to local management considerations.

Data collection for this study occurred in summer 2003. Field-based information was obtained by sampling stands using stratified sampling to represent forest units that had not had management activities in the previous 20 years and were 
located within $1.5 \mathrm{~km}$ of a road. A total of 136 stands were selected. Within each stand, a cruise line was established by randomly selecting the line's starting point and direction. Ten stations were established along the cruise lines approximately $20 \mathrm{~m}$ apart. At each station, all trees taller than $2 \mathrm{~m}$ were measured using a $2 \mathrm{BAF}$ wedge prism. The stand species composition was calculated by averaging tree basal area over the 10 stations. FRI-based species composition for the sampled stands was retrieved from FRI.

Each sampled stand was assigned to a planning forest unit based on species composition estimated in the field and the one available from FRI. Hereafter, these forest unit assignments are referred to as field- and FRI-based, respectively. Cross-comparison of FRI- and field data-based stand classification was conducted using (a) a simple count of classified stands in each of the forest units, and (b) area coverage of classified stands in each of the forest units. A "distance" between the two forest unit classification (FRI- and field databased) was also estimated for each sampled stand. Distance was estimated as the minimum change in FRI-based species composition required for the stand to be classified into the same forest unit as based on the field data. For example, the minimum distance between a stand with the FRI-based species composition Mr6Bw2Po1Bf1 and the planning unit BW (defined in the Nipissing Forest by a condition Bw + Po $\geq 5$ ) is equal to 2 (see footnote to Table 1 for species codes). In other words, one needs to increase the cumulative proportion of white birch (Bw) and poplar (Po) in the FRI-based species composition by $20 \%$ to meet the condition of planning forest unit BW; hence, the minimum change in FRIbased species composition for this stand is equal to $20 \%$.

\section{Results and Discussion}

A comparison of FRI- and field data-based stand classification results are presented in Tables 2 and 3. Column and row headers in Table 2 list FRI- and field data-based forest units, respectively. A cell (row I, column $J$ ) includes a fraction (\%) of stands classified as forest unit $I$ based on FRI that were classified as forest unit $J$ based on the field data; the last column shows the total number of sampled stands classified in FRI as forest unit $I$. Similarly, a cell (row $I$, column $J$ ) in Table 3 contains the ratio (\%) of area occupied by stands classified as forest unit $I$ and $J$ based on FRI and field data, respectively, to the total area of stands classified as forest unit $I$ in the FRI; the last column shows the total area of sampled stands classified in FRI as forest unit $I$. Once the stands were classified into planning forests units, sample sizes were very uneven, with the number of sampled stands per FRI-based forest units ranging from 1 to 25. The FRI-based forest units with a sample size of eight or more stands included BW, HDSEL, MCL, MW, PO, PWUS, SF (codes explained in Table 1); these units account for $74 \%$ of productive forest in the Nipissing Forest. These units were not presented in Tables 2 and 3 since the small sample size translated into an individual stand having a substantial influence on the results of comparison between FRIand field-based classifications.

The total number of stands classified to the same forest units both in FRI and in the field was about 54\%; for forest units with a field sample size greater than eight stands, the number was about $59 \%$ (Table 2). Similar results for area coverage (Table 3 ) were $56 \%$ and $62 \%$, respectively. Fig. 2 shows a breakdown of all sampled stands by minimum change in FRI-based species composition required for the stands to be classified into the same forest unit as based on the field data. As seen from Fig. 2, 10\%, 20\%, and 30\% change in FRI-based species composition would bring up to $74 \%, 87 \%$, and $94 \%$, respectively, the total fraction of stands classified to the same forest unit based on the FRI and field data. It should be noted, however, that these numbers are based not on an arbitrary or most probable change but on a directed "minimum" change required for the stand to be classified into the same unit.

The numbers in Tables 2 and 3 indicate about a $55 \%$ to $60 \%$ agreement between FRI- and field-based classifications of sampled stands into forest units. A number of factors may

Table 1. Descriptive statistics for Nipissing Forest planning forest units.

\begin{tabular}{|c|c|c|c|c|c|}
\hline $\begin{array}{l}\text { Forest } \\
\text { unit } \\
\text { code }\end{array}$ & Forest unit description & Weighted average species composition ${ }^{\mathrm{a}}$ & $\begin{array}{c}\text { Average } \\
\text { site } \\
\text { class }\end{array}$ & $\begin{array}{l}\text { Average } \\
\text { stocking }\end{array}$ & $\begin{array}{c}\text { Forest } \\
\text { area (ha) }\end{array}$ \\
\hline BW & White birch, poplar mix & Bw4Po2Mr1Bf1Mh1Sw1 & 2.0 & 0.88 & 70790 \\
\hline BY & Yellow birch & By4Mh2Bf1Mr1Sw1He1 & 1.7 & 0.80 & 13540 \\
\hline HDSEL & Tolerant hardwood selection & Mh6Or1By1Mr1He1 & 1.1 & 0.82 & 90990 \\
\hline HDUS & Tolerant hardwood uniform shelterwood & Mh3Or2By1Bw1He1Bf1Po1 & 1.6 & 0.79 & 41722 \\
\hline LWMX & Lowland mixedwood & Mr2Po2Ab1Bf1Bw1Ce1By1Sw1 & 1.6 & 0.76 & 26183 \\
\hline MCL & Mixed conifer lowland & Sb4Ce3La1Bf1Sw1 & 1.7 & 0.72 & 27537 \\
\hline MW & Mixedwood & Po2Bf2Bw2Sw1Mr1Sb1Pw1 & 1.7 & 0.74 & 82185 \\
\hline PJ & Jack pine & Pj8Sb1Po1 & 1.7 & 0.88 & 12145 \\
\hline PJSB & Jack pine upland black spruce mix & Sb3Pj3Po1Bw1Bf1Sw1 & 1.2 & 0.72 & 17756 \\
\hline $\mathrm{PO}$ & Poplar & Po6Bw1Bf1Mr1Sw1 & 2.2 & 0.79 & 48320 \\
\hline PR & Red pine & Pr8Bw1Po1 & 0.9 & 0.82 & 11730 \\
\hline PWST & White pine seed tree & Pw3Po2Bw1Pr1Bf1Sw1Sb1 & 1.8 & 0.59 & 25688 \\
\hline PWUS & White pine uniform shelterwood & Pw4Bw1Po1Pr1Sw1Bf1Mr1 & 1.4 & 0.71 & 68238 \\
\hline SF & Spruce / fir & Bf2Sb2Sw2Ce1Bw1Po1Pw1 & 1.2 & 0.70 & 56199 \\
\hline
\end{tabular}

aSpecies codes: Ab - black ash; Bf - balsam fir; Bw - white birch; By - yellow birch; He - eastern hemlock; Ce - eastern red cedar; La - larch (tamarack); Mh - sugar maple; Mr - red maple; Or - red oak; Po - poplar (trembling aspen); $\mathrm{Pj}$ - jack pine; $\mathrm{Pr}$ - red pine; $\mathrm{Sb}$ - black spruce; $\mathrm{Sw}$ - white spruce. 
Table 2. Comparison of FRI- and field-based classification of 136 stands in forest units. An individual cell (row I, column J) contains a fraction (\%) of stands classified as forest unit I in FRI and as forest unit $\mathrm{J}$ in the field. Fractions of identically classified stands are shown in bold.

\begin{tabular}{|c|c|c|c|c|c|c|c|c|c|c|c|c|c|c|c|}
\hline \multirow{2}{*}{$\begin{array}{l}\text { FRI- } \\
\text { based } \\
\text { forest } \\
\text { units }^{\mathrm{a}}\end{array}$} & \multicolumn{14}{|c|}{ Field-based forest units } & \multirow{2}{*}{$\begin{array}{c}\text { Number } \\
\text { of } \\
\text { stands }\end{array}$} \\
\hline & BW & BY & HDSEL & HDUS & LWMW & MCL & MW & PJ & PJSB & PO & PR & PWST & PWUS & SF & \\
\hline BW & 52.9 & 0.0 & 0.0 & 0.0 & 0.0 & 0.0 & 23.6 & 0.0 & 0.0 & 5.9 & 0.0 & 0.0 & 17.6 & 0.0 & 17 \\
\hline HDSEL & 0.0 & 0.0 & 87.0 & 0.0 & 0.0 & 0.0 & 13.0 & 0.0 & 0.0 & 0.0 & 0.0 & 0.0 & 0.0 & 0.0 & 23 \\
\hline MCL & 0.0 & 0.0 & 0.0 & 0.0 & 0.0 & 62.5 & 0.0 & 0.0 & 0.0 & 0.0 & 0.0 & 0.0 & 0.0 & 37.5 & 8 \\
\hline MW & 5.0 & 5.0 & 10.0 & 5.0 & 5.0 & 0.0 & 50.0 & 0.0 & 0.0 & 0.0 & 0.0 & 0.0 & 5.0 & 15.0 & 20 \\
\hline $\mathrm{PO}$ & 21.4 & 0.0 & 0.0 & 0.0 & 0.0 & 0.0 & 7.2 & 0.0 & 0.0 & 21.4 & 0.0 & 21.4 & 21.4 & 7.2 & 14 \\
\hline PWUS & 0.0 & 0.0 & 0.0 & 0.0 & 0.0 & 0.0 & 11.7 & 5.9 & 5.9 & 0.0 & 11.8 & 0.0 & 64.7 & 0.0 & 17 \\
\hline SF & 0.0 & 5.5 & 0.0 & 5.5 & 5.6 & 5.6 & 16.7 & 0.0 & 0.0 & 0.0 & 0.0 & 0.0 & 0.0 & 61.1 & 18 \\
\hline
\end{tabular}

${ }^{\mathrm{a}}$ only forest units represented by eight or more stands are included

Table 3. Comparison of FRI- and field-based classification of 136 stands in forest units. An individual cell (row I, column J) contains a fraction (\%) of area classified as forest unit I in FRI and as forest unit $\mathrm{J}$ in the field. Fractions of identically classified stands are shown in bold.

\begin{tabular}{|c|c|c|c|c|c|c|c|c|c|c|c|c|c|c|c|}
\hline \multirow{2}{*}{$\begin{array}{l}\text { based } \\
\text { forest } \\
\text { units }^{\mathrm{a}}\end{array}$} & \multirow[b]{2}{*}{ BW } & \multicolumn{13}{|c|}{ Field-based forest units } & \multirow{2}{*}{$\begin{array}{c}\text { Area of } \\
\text { stands } \\
\text { (ha) }\end{array}$} \\
\hline & & BY & HDSEL & HDUS & LWMW & MCL & MW & PJ & PJSB & $\mathrm{PO}$ & PR & PWST & PWUS & SF & \\
\hline BW & 72.5 & 0.0 & 0.0 & 0.0 & 0.0 & 0.0 & 12.2 & 0.0 & 0.0 & 5.3 & 0.0 & 0.0 & 10.0 & 0.0 & 728.1 \\
\hline HDSEL & 0.0 & 0.0 & 88.1 & 0.0 & 0.0 & 0.0 & 11.9 & 0.0 & 0.0 & 0.0 & 0.0 & 0.0 & 0.0 & 0.0 & 1026.9 \\
\hline MCL & 0.0 & 0.0 & 0.0 & 0.0 & 0.0 & 73.3 & 0.0 & 0.0 & 0.0 & 0.0 & 0.0 & 0.0 & 0.0 & 26.7 & 147.0 \\
\hline MW & 5.3 & 3.1 & 12.3 & 5.8 & 6.3 & 0.0 & 48.7 & 0.0 & 0.0 & 0.0 & 0.0 & 0.0 & 4.7 & 13.8 & 304.0 \\
\hline $\mathrm{PO}$ & 10.8 & 0.0 & 0.0 & 0.0 & 0.0 & 0.0 & 5.3 & 0.0 & 0.0 & 7.1 & 0.0 & 18.8 & 55.9 & 2.1 & 563.3 \\
\hline PWUS & 0.0 & 0.0 & 0.0 & 0.0 & 0.0 & 0.0 & 22.2 & 2.5 & 5.9 & 0.0 & 7.1 & 0.0 & 62.3 & 0.0 & 323.2 \\
\hline SF & 0.0 & 6.2 & 0.0 & 9.6 & 4.2 & 7.0 & 17.1 & 0.0 & 0.0 & 0.0 & 0.0 & 0.0 & 0.0 & 55.9 & 270.8 \\
\hline
\end{tabular}

a only forest units represented by eight or more stands are included

have contributed to a mismatch in forest units. First, our results are presented in terms of forest units, not the actual species composition. The difference between FRI- and fieldbased species composition for a given stand can be relatively small (e.g., 10\%) but the stand can be assigned to different forest units thus contributing to the low agreement between FRI- and field-based classification. Second, the species composition could have changed between when FRI was produced (1989) and the year of field data sampling (2003). As seen from Fig. 2, the agreement between FRI- and field-based classification of forest units could be higher, e.g., in the $70 \%$ to $75 \%$ range assuming a $10 \%$ change in FRI-based species composition. Third, the FRI- and field-based estimates of stand species composition relied on the use of cruise lines. In the FRI, photos were calibrated using cruise lines established subjectively in a limited number of selected stands. In our study, the cruise lines were established randomly in each sampled stand. Both methods may introduce additional bias if the stands are not homogeneous in terms of species composition.

Despite these factors, our results are within the range of values produced by the forest resource inventory audit in $\mathrm{BC}$,
1992-1999 (BCMoF 2001). This audit was undertaken to validate the FRI information for each of BC's 37 Timber Supply Areas (TSAs, administrative units, similar to FMU in Ontario). In each TSA, mature (greater than 60 years old) forest stands were sampled for various stands attributes including species composition; the number of sampled stands per TSA varied from 46 to 130, with the majority of TSAs having 50 stands sampled. For each stand, species composition measured in the audit and available in the FRI was converted into growth type groups (BC-specific aggregation of forest stands, similar in concept to forest units in Ontario). For each TSA, the audit- and FRI- based growth type groups were cross-tabulated using the same approach as presented in Table 2. The agreement between the audit- and FRI- based growth type groups varied by TSA from $32 \%$ to $84 \%$, with the average agreement being equal to $57 \%$ (calculated by the authors of this manuscript based on the audit reports for individual TSAs). This number is very close to the level of agreement between FRI- and field-based forest units obtained in our study. It should be noted that species composition in young stands (younger than 60 years old) was evaluated in BC's 


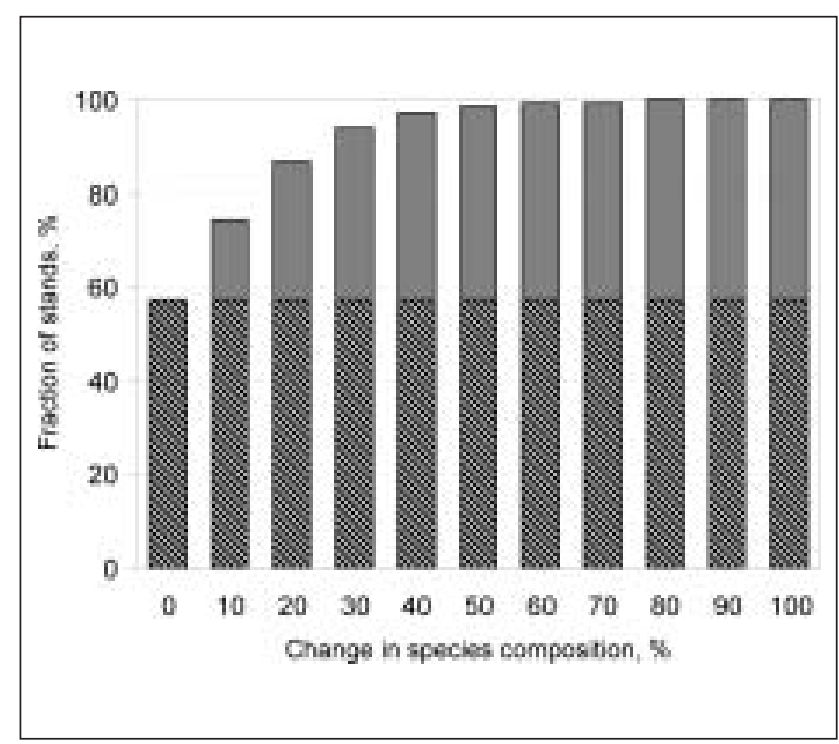

Fig. 2. Proportion of stands classified into the same forest unit based on FRI and field data. Diagonal-striped bars are the percentage of FRI and cruised stands that match planning Forest Units without any change to their composition; shaded bars are the additional fraction of stands for a given minimum change in FRI-based species composition.

audit with a separate sample of stands, and showed less agreement (between 6\% and 60\%) between the audit- and FRIbased growth type groups than for mature stands. Nevertheless, this consistency in results between our study and the $\mathrm{BC}$ audit emphasizes the challenges of assessing stand species composition, and suggests a need for more extensive studies on FRI validation prior to its use for forest management planning.

Estimates in Table 2 can be interpreted as probabilities of forest unit classification, i.e., for any given stand identified in the FRI as some forest unit, the values in Table 2 provide probabilities of this stand belonging to this or other forest units. Estimates in Table 3 can be used to adjust forest unit area coverage. The latter adjustment can be used in assessing growing stock in the FMU, preparing input data for timber supply modelling, estimating wildlife habitat area, and other forest management applications.
The values in Tables 2 and 3 represent only the Nipissing Forest FRI and cannot be applied to other forests without similar validation studies. As well, the impact of the low level of agreement between the aerial photography-derived FRI and the ground survey-derived stand composition on timber and habitat supply remains unclear. Further work using wood and habitat supply computer models is required to determine these impacts.

\section{Acknowledgements}

This study was funded by the Forest Analysis and Modelling Unit, Ontario Ministry of Natural Resources with in-kind contributions from Nipissing Forest Resource Management Inc., and the Forest Research Partnership. We thank Chris Lyons, Julie Lyons and Tim Martens for the collection of field data. We also thank Dianne Othmer, Ken McCulloch and Lisa Buse, all with the Ontario Ministry of Natural Resources, for their help in organizing the collection of field data, assisting with data processing and editing earlier draft of this manuscript, respectively. We also thank two anonymous reviewers who provided valuable comments on an earlier draft of this manuscript.

\section{References}

British Columbia Ministry of Forests (BCMoF). 2001. Forest Inventory Audit Program. [online]. Available from http://www.for. gov.bc.ca/hts/vri/audits/index.html [cited 27 December 2006].

Cottam, N.B. and P. Street. 2004. Forest Management Plan for the Nipissing Forest. Nipissing Forest Resource Management Inc., Callander, Ontario.

Gillis, M.D. and D.G. Leckie. 1993. Forest inventory mapping procedures across Canada. Forestry Canada, Petawawa National Forestry Institute, Ottawa, Information Report PI-X-114. 79 p.

Hyyppa, J., M. Inkinen, M. Engdahl, S. Lunko and Y. Zhu. 2000. Accuracy comparison of various remote sensing data sources in the retrieval of forest stand attributes. Forest Ecology and Management 128(2): 109-120.

McRoberts, R.E., G.A. Reams, P.C. Van Deusen and J.W. Moser. 2003. Proceedings of the Third Annual Forest Inventory and Analysis Symposium, October 17-19, 2001, Traverse City, MI. USDA Forest Service, North Central Research Station, St. Paul, MN. General Technical Report NC-230. 208 p.

Ontario Ministry of Natural Resources (OMNR). 2004. Forest management planning manual for Ontario's Crown forests. Ontario Ministry of Natural Resources. Queen's Printer for Ontario. Toronto, Ontario. $440 \mathrm{p}$. 